\title{
Development of Water Resources for Micro Watershed at Chinamushidiwada Village in Visakhapatnam, Andhra Pradesh, India
}

\section{Kiran Jalem*}

Central University of Jharkhand Ranchi, Jharkhand, India

\begin{abstract}
An attempt made to develop water resource for micro watershed of Visakhapatnam Urban Area. The study area extends from $17^{\circ} 47^{\prime} 02^{\prime \prime} \mathrm{N}$ to $17^{\circ} 48^{\prime} 38^{\prime \prime} \mathrm{N}$ latitudes and $83^{\circ} 11^{\prime} 51^{\prime \prime} \mathrm{E}$ to $83^{\circ} 14^{\prime} 45^{\prime \prime} \mathrm{E}$ longitudes, covering an aerial extent of $9.18 \mathrm{~km}^{2}$. A detailed examination of the existing three tanks in the study area is carried out using both spatial technology and ground based observations. The alteration of the terrain topography is studied from the survey of India toposheets and Total Station survey conducted in the study area. The 3-Dimensional terrain model is generated and the drainage network is simulated to study its interaction with the results of the change detection analysis. For the quantification of surface water bodies, Total Station survey is carried out for the tanks. Geophysical explorations are carried out, which identifies the thicknesses of top soil, weathered rock, fractured rock, hard fractured rock and hard rock formations, to assess the volume of the groundwater that can be stored in the aquifer system.
\end{abstract}

Keywords: Aquifer; 3-Dimensional terrain model; Geophysical; Total station; Visakhapatnam

\section{Introduction}

The complex and various interrelations between activities on the territory of the watershed cause that any considerable change of affectation of the land can have impacts on the management and the availability of the water in the basin; the production of goods, services, and the prosperity of the general population [1]. High amounts of impervious cover have been associated with stream warming, habitat alteration, and decreased aquatic integrity in urban areas [25]. In highly developed areas, options for improving storm water management exist, but are more limited and less likely to result in high quality water [6]. Several studies indicate that streamside forests offer significant protective effect [7].

Historically, zoning has been used to establish limits on building density and to separate uses believed to be inherently incompatible [8]. Watershed-based zoning, in contrast, uses watershed and sub-watershed boundaries as the basis for making land use decisions. Typically, zoning objectives focus on maintaining or reducing impervious cover in sensitive sub-watersheds and redirecting development to subwatersheds that are better able to absorb their influence [9].

The impact of human activities including urbanization, land use changes, groundwater contamination and over exploitation etc. requires protection of these valuable resources. Techniques to adequately assess these impacts requires the methods for quantifying the recharge, geophysical characteristics of the aquifers and modeling the contamination transport, within the watershed, at different temporal and spatial scales. GIS modeling of flow characteristics contribute to the understanding, quantification and transport processes in complex hydrogeological systems and used in practical approaches to assess the water quality, protection methods, solutions to contamination problems. To meet the growing challenges on these resources, an integrated water resources management at micro level is needed.

\section{Study Area}

The study is aimed at identifying the complex system of surface runoff in a semi urban system, between $17^{\circ} 47^{\prime} 02^{\prime \prime} \mathrm{N}$ to $17^{\circ} 48^{\prime} 38^{\prime \prime} \mathrm{N}$ latitudes and $83^{\circ} 11^{\prime} 51^{\prime \prime} \mathrm{E}$ to $83^{\circ} 14^{\prime} 45^{\prime \prime}$ E longitudes, covering an aerial extent of $9.18 \mathrm{~km}^{2}$. It is a part of survey of India (SOI) Toposheets- 65 $\mathrm{O} / 1 \mathrm{SE}$ of 1:25,000 scale and is within the administrative boundaries of greater Visakhapatnam municipal corporation (GVMC) of Visakhapatnam, Andhra Pradesh (Figure 1]) It includes the tanks existing at Sujatha nagar, Laxmipuram and Chinamushidiwada. Because of rapid urbanization there is an urgent need to protect these valuable water resources. A brief description of these tanks is given below and the sub-watershed boundaries for these tanks are shown in Figure $2 b$.
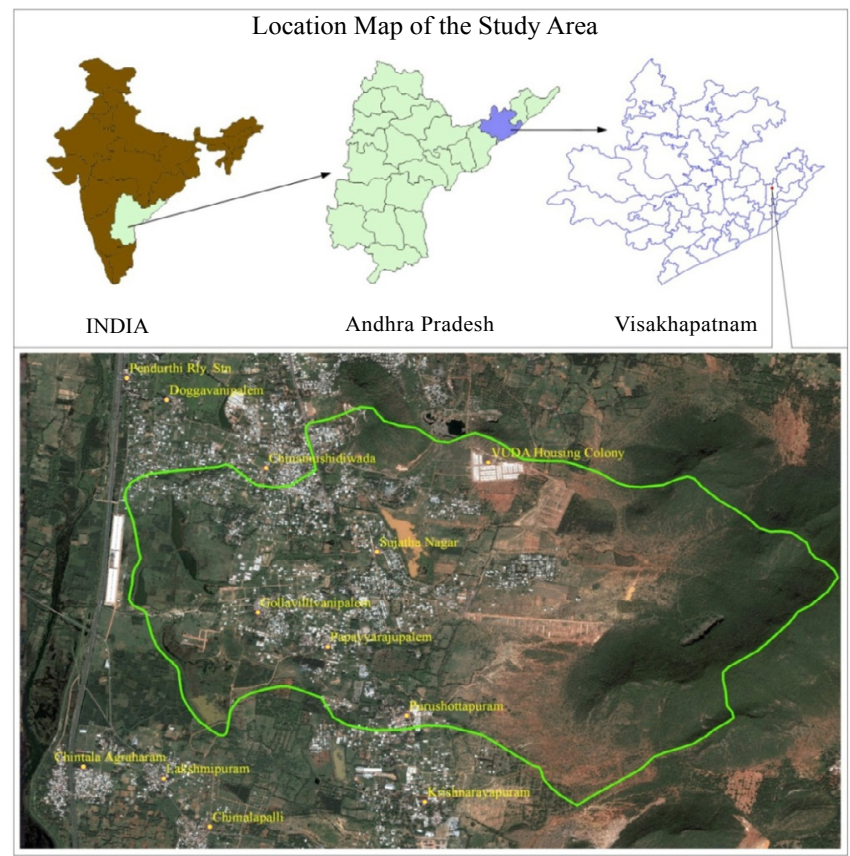

Figure 1: Location map of study area.

*Corresponding author: Kiran Jalem, Central University of Jharkhand Ranchi, Jharkhand, India, Tel: 07631097575; E-mail: jalemkiran@gmail.com

Received October 22, 2016; Accepted December 05, 2016; Published December 15,2016

Citation: Jalem K (2016) Development of Water Resources for Micro Watershed at Chinamushidiwada Village in Visakhapatnam, Andhra Pradesh, India. J Civil Environ Eng 6: 258. doi: 10.4172/2165-784X.1000258

Copyright: () 2016 Jalem K. This is an open-access article distributed under the terms of the Creative Commons Attribution License, which permits unrestricted use, distribution, and reproduction in any medium, provided the original author and source are credited. 
Citation: Jalem K (2016) Development of Water Resources for Micro Watershed at Chinamushidiwada Village in Visakhapatnam, Andhra Pradesh, India. J Civil Environ Eng 6: 258. doi: 10.4172/2165-784X.1000258

Page 2 of 10

Sujatha nagar tank: The tank (Figure 3a) is located in the midst of the highly-urbanized area called Sujatha nagar and is at the latitude $17^{\circ}$ $48^{\prime \prime} 08^{\prime \prime} \mathrm{N}$ and $83^{\circ} 12^{\prime \prime} 52^{\prime \prime} \mathrm{E}$ longitude. Entire Ayacut area under this tank is completely developed into well planned colonies. Tank bed area is about 8.0 hectares and there are indications that the tank bed being occupied by the unauthorized colonies. There is large catchment to this tank originating from the west face of the Kambalakonda forest.

Chinamushidiwada tank: The tank (Figure $3 \mathrm{~b}$ ) is located to the west of Chinamushidiwada village at $17^{\circ} 48^{\prime} 10^{\prime \prime} \mathrm{N}$ latitude and $83^{\circ} 11^{\prime}$ $57^{\prime \prime}$ E longitude. All around the tank the land is under urban use for residential layouts. Tank bed area is about 5.1 hectares and is fed from its catchment as well excess water from Krishna rayapuram tank.

Laxmipuram tank: The tank (Figure 3c) is located at the latitude $17^{\circ} 47^{\prime} 40^{\prime \prime} \mathrm{N}$ and longitude $83^{\circ} 11^{\prime} 59^{\prime \prime} \mathrm{E}$ and the nearest village is Laxmipuram, which is a part of GVMC. Tank bed area is about 20.4 hectares and is a medium irrigation tank under which about 500 acres of paddy being cultivated every year. Some part of the Ayacut is converted into urban land and still the remaining area being irrigated. In another 4 to 5 years the entire ayacut area will be converted into urban land use. Hence there is a need to convert this tank into urban water storage tank, the storage of which becomes a good dependable source to the residents in the Laxmipuram and Chinamusidiwada area.

\section{Identification of the Problem}

At present the storm water from the city area drains into nearby rainwater stream locally known as gedda. These geddas, depending upon the topography, have accomplished natural paths and confluences each other before reaching sea at various locations. In certain localities of the city near to the sea such as near Taj Residency, All India radio station, VUDA Park, Ramakrishna beach etc. storm water gets discharged directly into the sea and also into back waters. Some portion of the town near to sea is occupied with elevated areas and the road side drains and natural streams within the area discharge storm water directly into the sea.

Due to the rapid urbanization and un-precedent growth of the city in the past two decades, most of the storm water drains are encroached by slum-dwellers (Figures $4 \mathrm{a}$ and $4 \mathrm{~b}$ ) as well as modern apartments, thereby causing obstructions to the free flow of stream and narrowdown the width furthermore.

The nearby residents are habituated to throw the debris and other wastages into the drains due to lack of proper demarcation and fencing of storm water drains. This has resulted in silting of drains and reducing its the carrying capacity (Figure $4 \mathrm{c}$ ). Cattle pollution is found to be predominant in the study area (Figure $4 \mathrm{~d}$ ).

During heavy rains the problem gets complicated due to stagnant

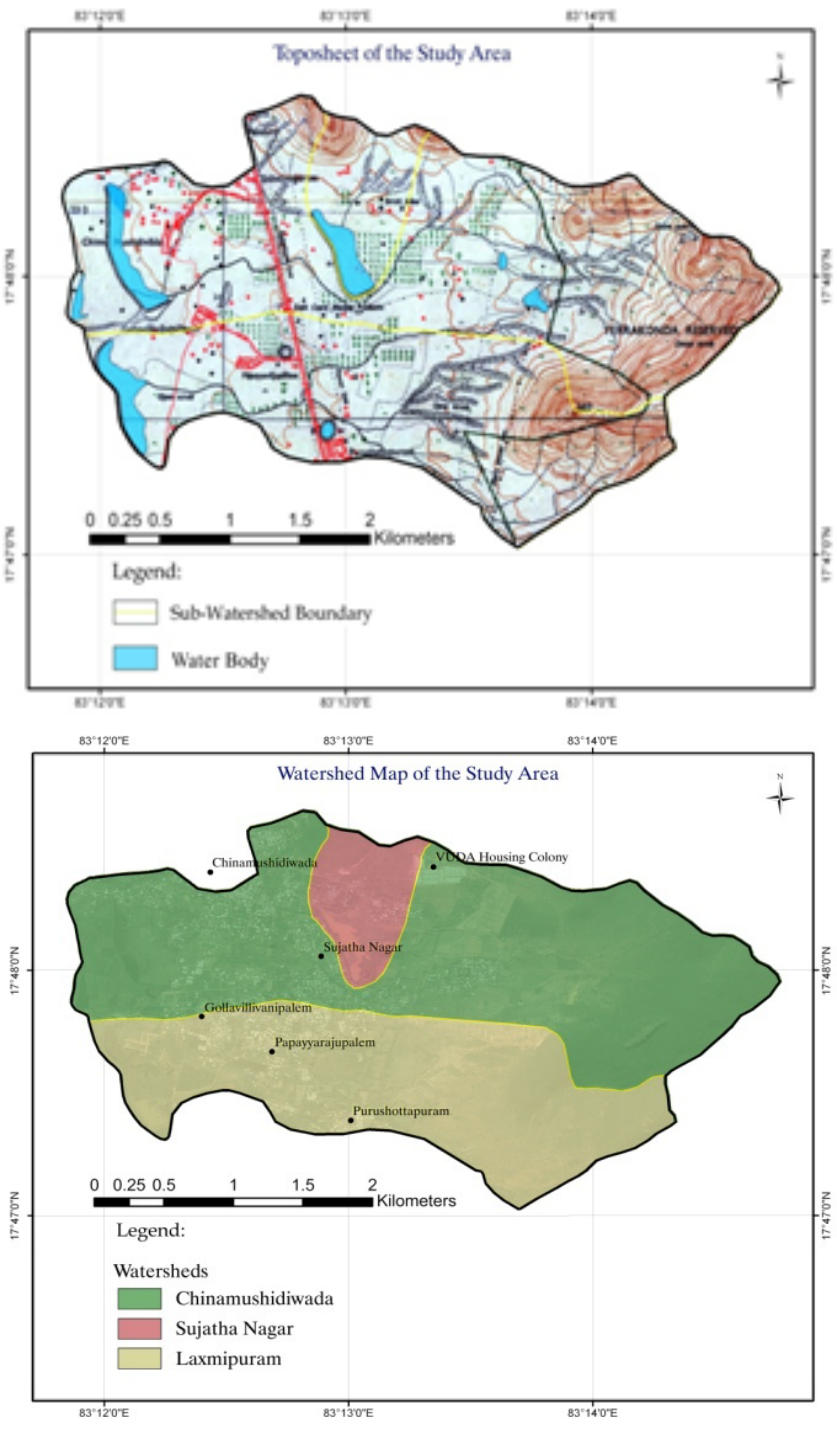

Figure 2: Toposheet of study area (a) and subwatershed boundaries (b).

conditions and the low-lying areas are severely affected. On the other hand, the illegal occupants, surrounding the tank area, are damaging the retaining structures (tank bund, weirs, spill ways etc.) to prevent water logging in their premises (Figures $4 \mathrm{e}-4 \mathrm{~g}$ ).

As fast developments are expected in near future it is utmost important for regularisation of storm water drains and demarcation of lands for storm water drain networks before the city grows haphazardly.

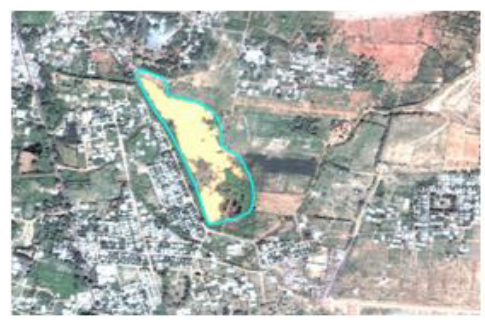

a

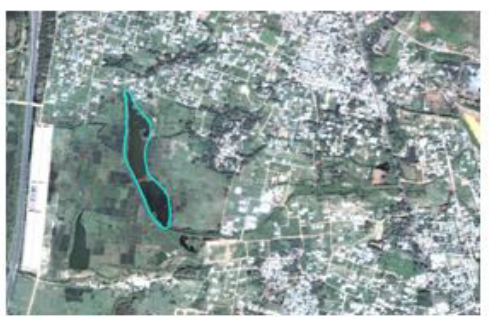

b

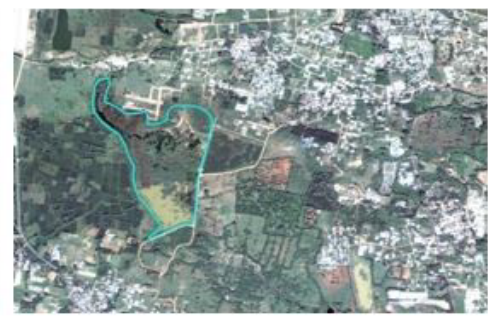

c

Figure 3: Satellite image of Sujatha nagar tank (a), Chinamushidiwada tank (b) and Laxmipuram tank (c). 


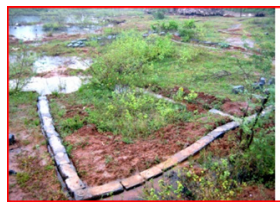

(a)

(c)

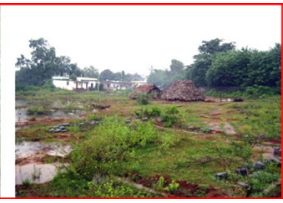

(d)

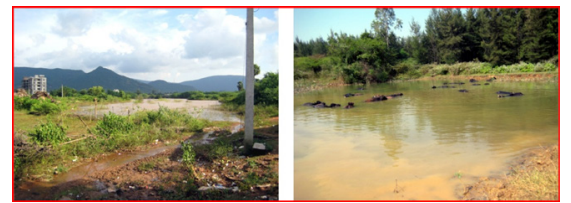

(b)

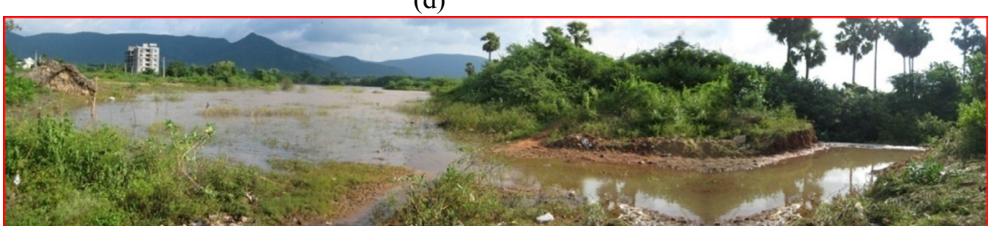

(e)

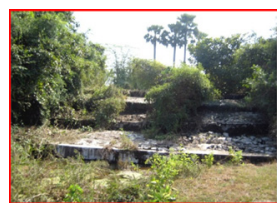

(f)

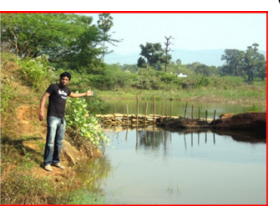

(g)

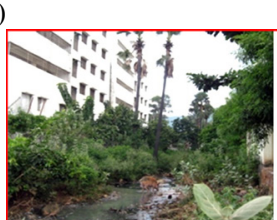

)

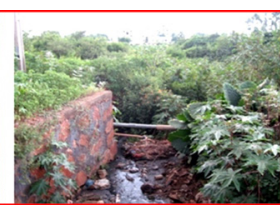

(h)

Figure 4: Occupations observed in the Sujatha nagar tank bed area (a) (b), Debris around the Sujatha nagar tank (c) and cattle pollution in Chinamushidiwada tank (d), A panoramic view of Sujatha nagar tank, showing the damaged weir (e), Vegetation growth across the weir (f) and breaching along Laxmipuram tank bund (g), Existing geddas with silt (h) and vegetation (i).

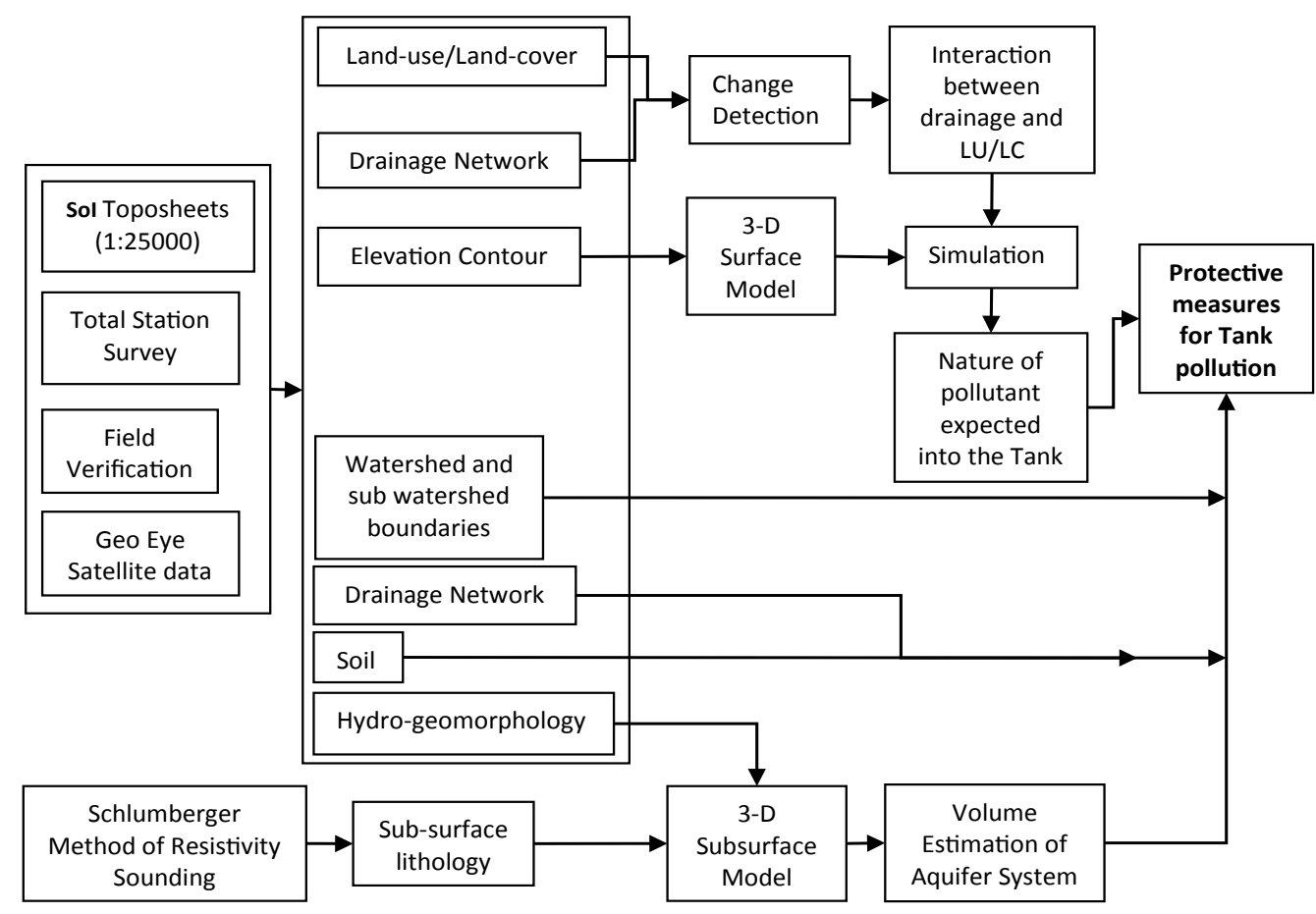

Figure 5: Flow diagram of overall methodology.

Presently in peripheral areas of the city, like our study area, the drains pass through undeveloped areas with growth of vegetation all along drains. Most of the geddas are not properly trained and defined with side walls and as such there is every need to train them by constructing RCC drains in the well developed areas and stone masonry trapezoidal drains in peripheral areas, which are likely to grow in near future.

At few stretches, the geddas are encroached. These need to be widened for smooth flow of storm runoff without affecting day to day life and also minimizing damages to properties and loss of human life during heavy rains. Few of the following exhibits indicate the existing condition of geddas near Sujatha nagar area (Figure $4 \mathrm{~h}$ ) and Laxmipuram (Figure 4i), needs the remodelling of the same.

\section{Data and Methodology}

Figure 5 depicts the overall methodology adopted for this study. Watershed boundary is demarcated for the study area, which include tanks at Sujatha nagar, Chinamushidiwada and Laxmipuram, over the 1:25,000 SoI toposheet, along with the sub watershed boundaries for 
each tank (Figure 3b). Thematic maps of land use/cover (Figure 6a), hydro-geomorphology (Figure 6b) and soil (Figures 7a and 7b) of the study area are prepared using the Geo-Eye satellite imagery and SOI toposheets along with field verifications. Topographical survey of the tank/storage system is conducted using total station (Figures $8 \mathrm{a}$ and $8 \mathrm{~b}$ ), to identify the existing tank boundaries, along with the high resolution Geo-Eye satellite imagery. Tank area existed on the toposheet is demarcated and the difference in the aerial extent of the tanks, from toposheet and Total Station survey, is computed. A 3-Dimensional terrain model of the study area is generated, using contours from the SOI toposheet and survey data from Total Station, along with field verifications. Change detection analysis is carried out by preparing temporal resolution land use/cover maps (Figure 9) to identify the interactions between drainage and land use/cover features. Drainage network is simulated over the 3-Dimensional surface model, which is compared to the existing drainage network and integrated with the change detection analysis results for assessing the nature of pollution expected into the tanks.

Subsurface lithology is identified using Schlumberger method of
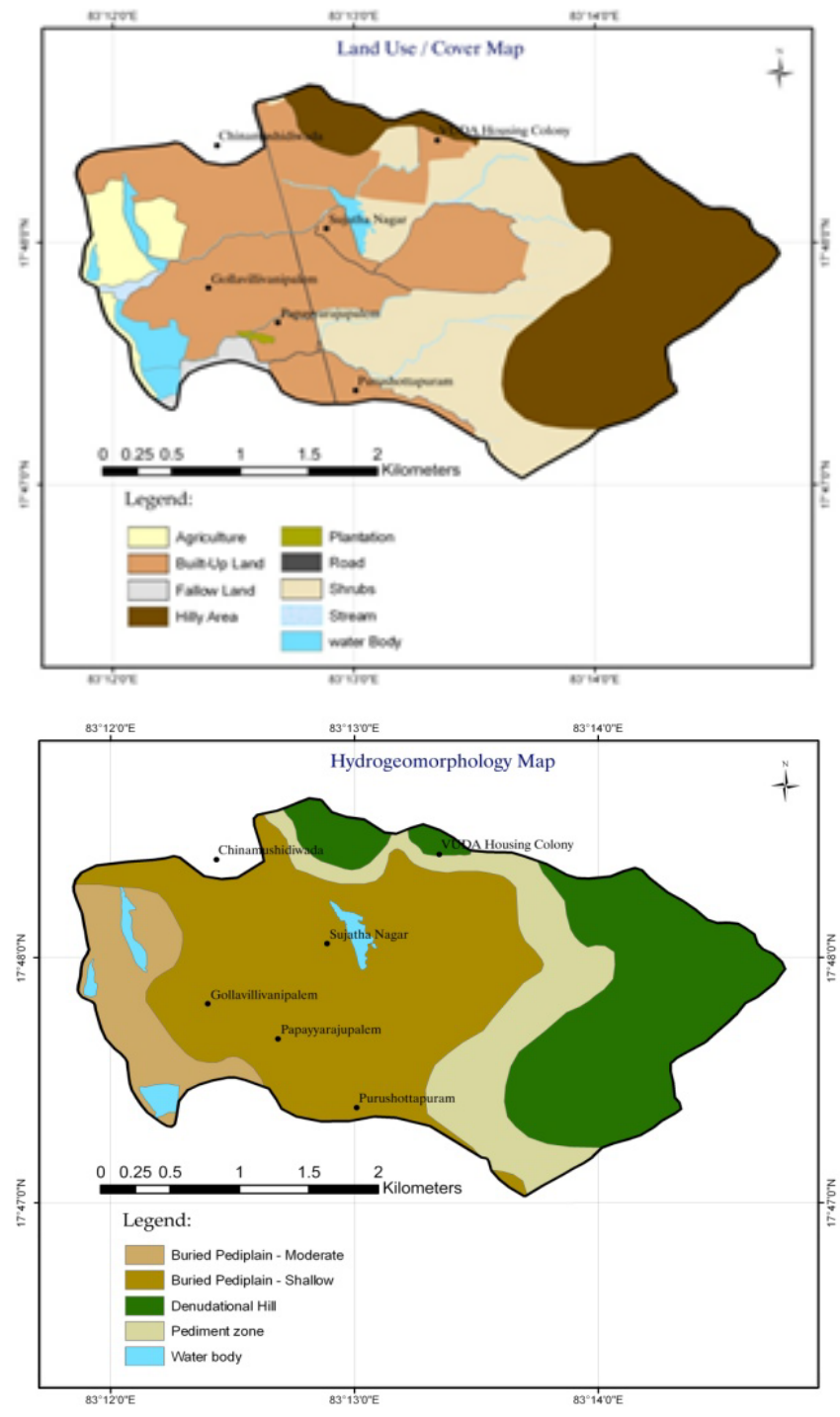

Figure 6: Land use/cover map (a) and hydrogeomorphology map (b) of the study area.
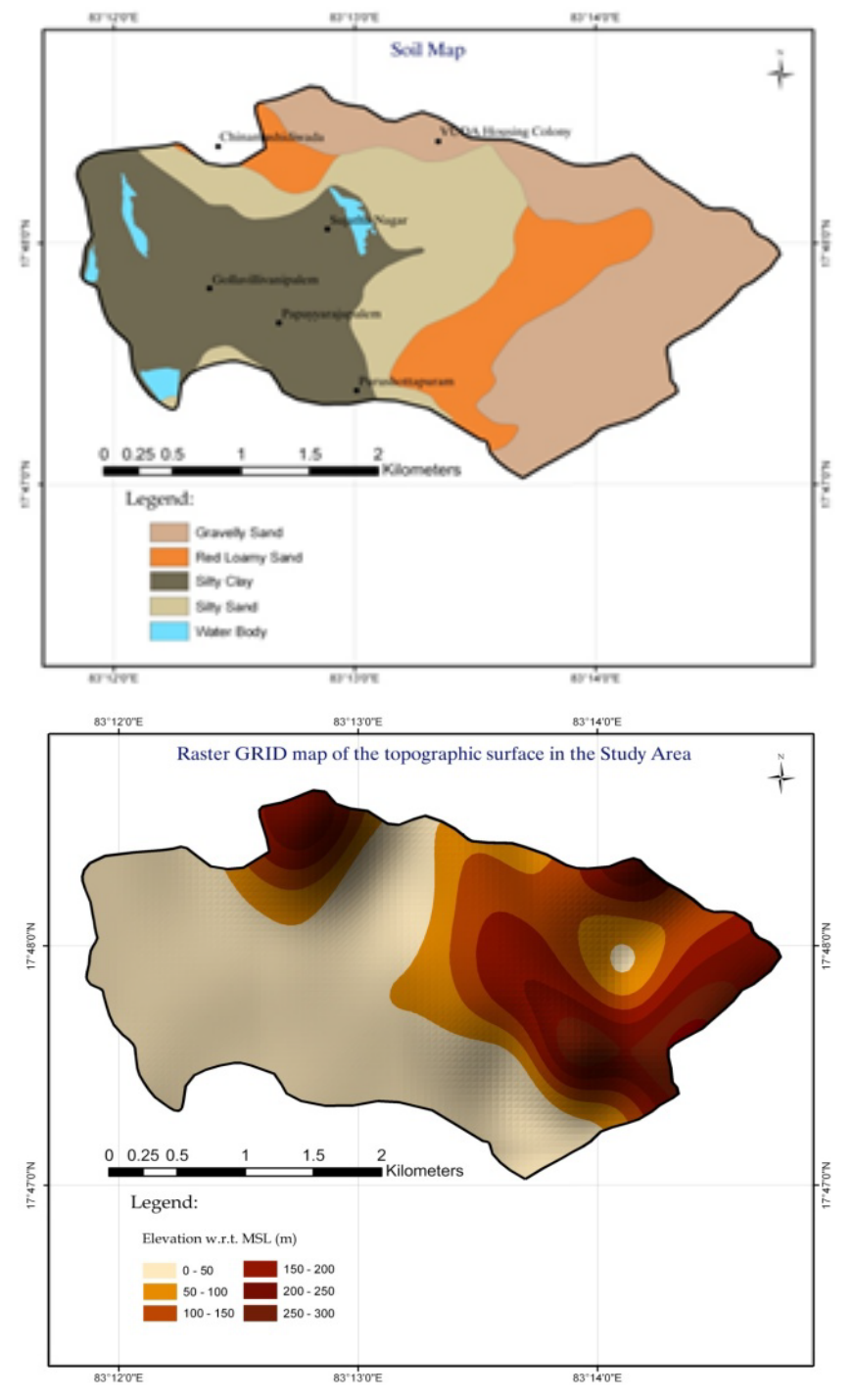

Figure 7: Soil map (a) and topographic surface map (b) of the study area.

resistivity soundings and the 3-dimensional models of different strata i.e. weathered, fractured, hard fractured, hard rock etc., are prepared. The volume of the aquifer is calculated using the 3-Dimensional subsurface models.

\section{Total station survey}

Total station survey has been carried out in the study area (Figure 8a) and used along with the contours extracted from 1:25,000 SOI toposheet to construct GRID data models for the topographic surface (Figure 7b) and subsurface layers. For highest accuracy in compensating for the errors resulting from the measurements it was made in both directions i.e. horizontal and vertical and then averaged. Watershed boundaries for each tank were demarcated over the Survey of India toposheet and the aerial extents of the tanks were computed as shown in Figure 8a.

\section{Generation of slope map}

Slop measures the rate of change of elevation at a surface location. Slope is one of the important parameters in drainage basin morphology. To prepare a general slope map using toposheets, the vertical drop 
Citation: Jalem K (2016) Development of Water Resources for Micro Watershed at Chinamushidiwada Village in Visakhapatnam, Andhra Pradesh, India. J Civil Environ Eng 6: 258. doi: 10.4172/2165-784X.1000258

Page 5 of 10
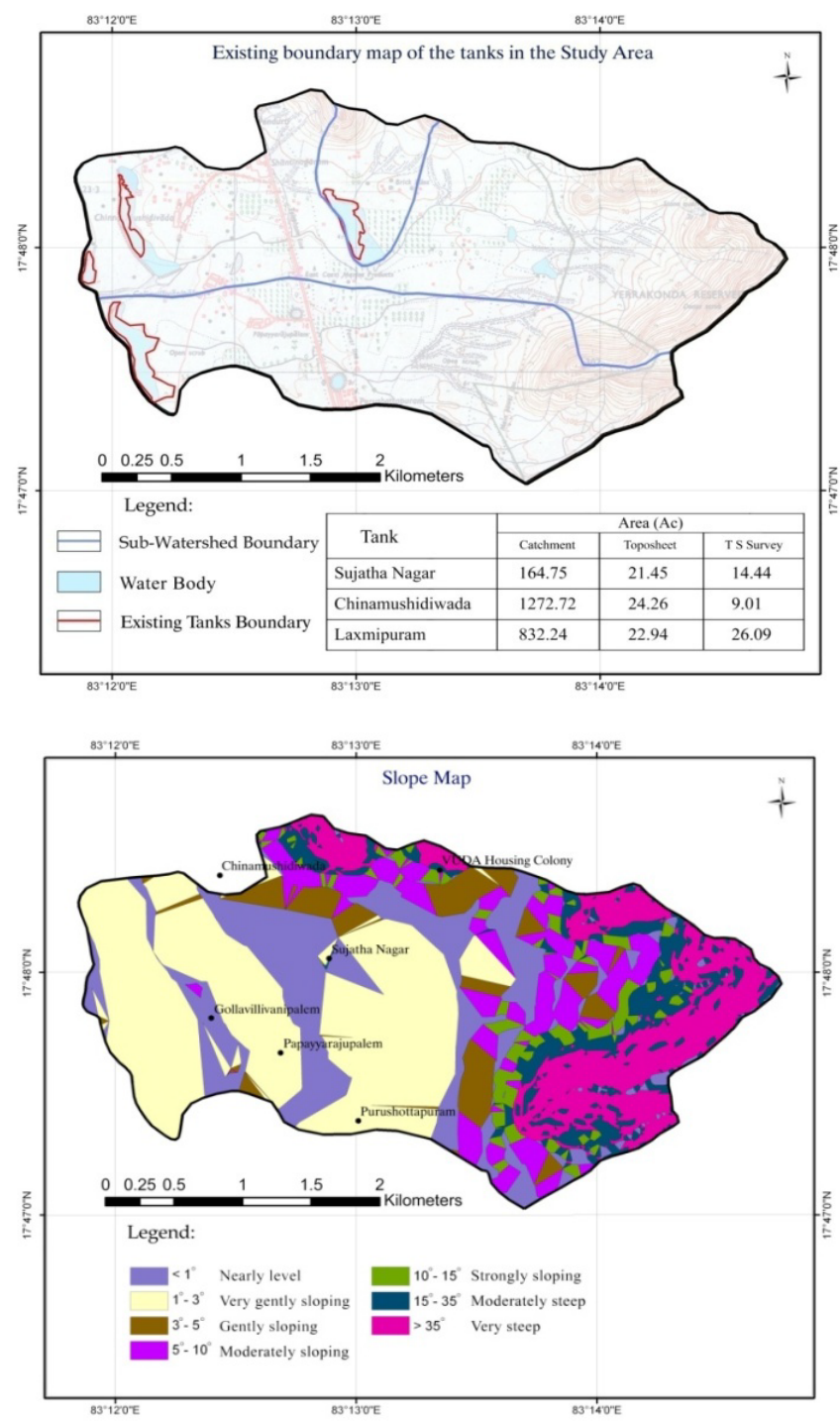

Figure 8: Slope map (a) of the study area (b) and total station survey.

was measured from the contour intervals and the horizontal distance in between contours was measured from the maps by multiplying the map difference with the scale factor. Closely spaced contours on the map indicates higher percentage of slopes as compared to fewer contours in the same space. Thus, density of contours on the map was used for preparing the slope map that gives various groups of slopes.

Slope classification and the limits of contour spacing according to national remote sensing centre (NRSC) are divided into seven categories. The classes of slopes and the corresponding contour spacing on 1:50,000 scale toposheets are given in Table 1 .

Using the Arc GIS 3D Analyst module, slope map with the above categories have been generated over the GRID of topographic surface Figure 8 b. Almost $20 \%$ of the study area is exhibiting strong to very steep slopes reflecting the high relief conditions. Nearly $70 \%$ of the area is nearly level to very gently sloping, which is a favorable condition to increase the water holding capacity of the terrain.

\section{3-Dimensional subsurface modeling}

Geophysical methods provide information about the physical properties of the earth's subsurface. There are two general types of methods: Active, which measure the subsurface response to electromagnetic, electrical, and seismic energy; and passive, which measure the earth's ambient magnetic, electrical, and gravitational fields. Geophysical methods can also be subdivided into either surface or borehole methods. Surface geophysical methods are generally nonintrusive and can be employed quickly to collect subsurface data Borehole geophysical methods require that wells or borings be drilled in order for geophysical tools to be lowered through them into the subsurface.

Electrical resistivity, also referred to as galvanic electrical methods, is useful for determining shallow and deep geologic and hydro-geologic

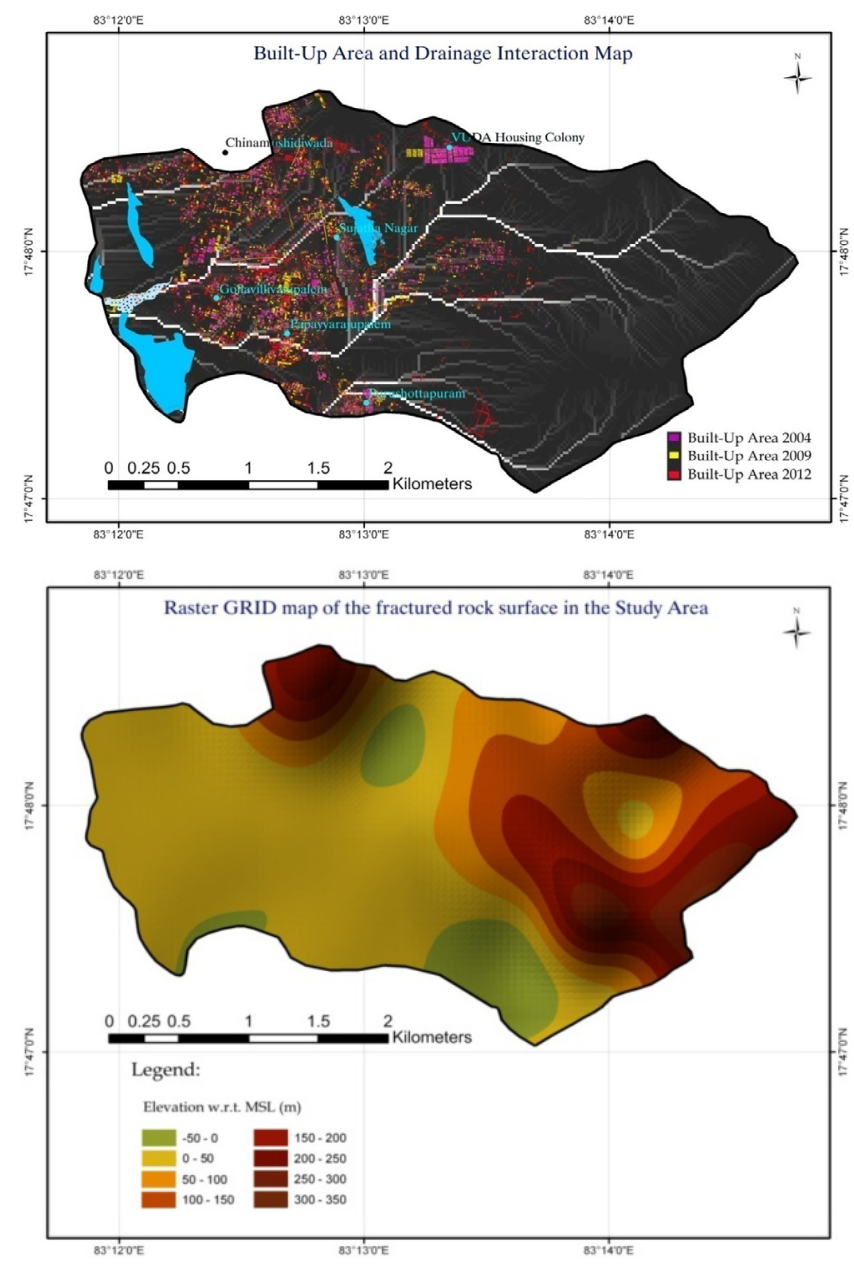

Figure 9: (a) Simulation of built-up area and drainage pattern of the study area. (b) Raster GRID map of the fractured rock surface.

\begin{tabular}{|c|c|c|c|}
\hline Category & $\begin{array}{r}\text { Percentage of } \\
\text { slope (degree) }\end{array}$ & $\begin{array}{r}\text { Spacing between two } \\
\text { successive contours }\end{array}$ & Type \\
\hline 1 & $<1$ & $>4 \mathrm{~cm}$ & Nearly level \\
\hline 2 & $1-3$ & $1.33 \mathrm{~cm}-4 \mathrm{~cm}$ & Very gently sloping \\
\hline 3 & $3-5$ & $0.8 \mathrm{~cm}-1.33 \mathrm{~cm}$ & Gently sloping \\
\hline 4 & $5-10$ & $0.4 \mathrm{~cm}-0.8 \mathrm{~cm}$ & Moderately sloping \\
\hline 5 & $10-15$ & $0.26 \mathrm{~cm}-0.4 \mathrm{~cm}$ & Strongly sloping \\
\hline 6 & $15-35$ & $0.11 \mathrm{~cm}-0.26 \mathrm{~cm}$ & Moderately steep \\
\hline 7 & $>35$ & $<0.11 \mathrm{~cm}$ & Very steep \\
\hline
\end{tabular}

Table 1: NRSC categorization of slopes. 
conditions. By measuring the electrical resistance to a direct current applied at the surface, this geophysical method was used to:

- Locate fracture zones, faults, karst, and other preferred groundwater contaminant pathways

- Locate clay lenses and sand channels

- Locate perched water zones and depth to groundwater

- Occasionally, locate large quantities of residual and floating product.

\section{Generation of subsurface models (GRID)}

The interpreted resistivity data is correlated with the observed geological and hydro-geological field data and the layers are classified into top soil, weathered rock, fractured rock and hard rock.

Top soil: It is the deposited soil over the rock formation by fluvial action. Boulders, pebbles and gravel mixture (colluviums) are observed over the hill slopes as top soil. Laterite gravel and sandy loam soils are present in the undulating plains. Silty loam and silty clay soils (alluvium) are observed in the valley fills, flood plains and adjacent to stream courses, where presently agricultural activity still exists. Top soil thicknesses vary between $1 \mathrm{~m}$ over the hill slopes to a maximum of $5 \mathrm{~m}$ in the valley fills and low lying areas.

Weathered rock: It is the top part of the basement rock and is highly weathered that changes its physical form. Original rock material loses its compactness and disintegrated to clay, silt, and and gravel with lot of pore space between the particles. Though the rock has good porosity, the permeability is medium due to the presence of fine material like clay and silt. Thickness of weathered mantle is high in the plains area and is thin or not present over the hill slopes and the variation is shown in Figure 10a.

Fractured rock: It is also the part of the basement rock where the number of fractures that are developed in the rock, may be interconnected or limited to surface area. The width of the fractures may range between few millimetres to centimetres. Fractured rock exists below the weathered rock and groundwater recharge in it takes place through leaky aquifer system. Groundwater permeability through the fractured rock openings will be very high compared to weathered rock, mainly due to the low percentage of fine materials like clay and silt in the fractured zones and the occurrence of its surface depth with respect to MSL.

Hard rock: It is the unaltered basement rock, having hairline cracks in it and may not be interconnected. Porosity of the hard rock will be negligible and there is no possibility of forming an aquifer system. The basement rock observed in the study area belongs to khondalite. Geophysical data and some bore well data shows that the occurrence of hard rock varies between $2 \mathrm{~m}$ to $100 \mathrm{~m}$ below the ground level and shown in Figure 10b.

\section{Discussion and Suggestions}

\section{GIS analysis}

Aquifers are geologic formations-layers of sand, gravel and rockwhere significant amounts of water can be stored, transported or supplied to well or a spring. They are irregular in shape, and can be close to the surface, or very deep. We use aquifers as a source of drinking water and to irrigate crops or to use in industry by pumping water from the aquifer using a well. As with any container of water, pumping from the aquifer empties it or at least decreases the amount of water it holds.
The unregulated development of groundwater occurred particularly in the arid and semi-arid areas and emerged the problems with overdraft and associated quality [10]. Aquifers are refilled or recharged in areas where they are exposed on the surface of the earth. Water can reenter the aquifer in these recharge areas. Groundwater flows through aquifers from areas of recharge to areas of discharge and it is not well known what the potential capacity of subsurface storage is [11].

The need for subsurface storage is steadily growing because of increasing water demands due to growing population, catchment degradation, changes in rainfall regime as a result of climate change etc. The volume assessment becomes one of the prime factors in risk analysis applied to groundwater reservoir evaluations [12]. Hence, the study is focused on estimating the aquifer volume using 3-Dimensional modeling and geostatistical techniques, which provide best linear unbiased estimations of unknown thicknesses [13-15]. Jaiswal et al. [16] have used GIS technique for generation of groundwater prospect zones towards rural development [17-21] have used GIS to delineate groundwater potential zone. GIS has been applied to groundwater potential modelling by $[22,23]$ have applied GIS for processing

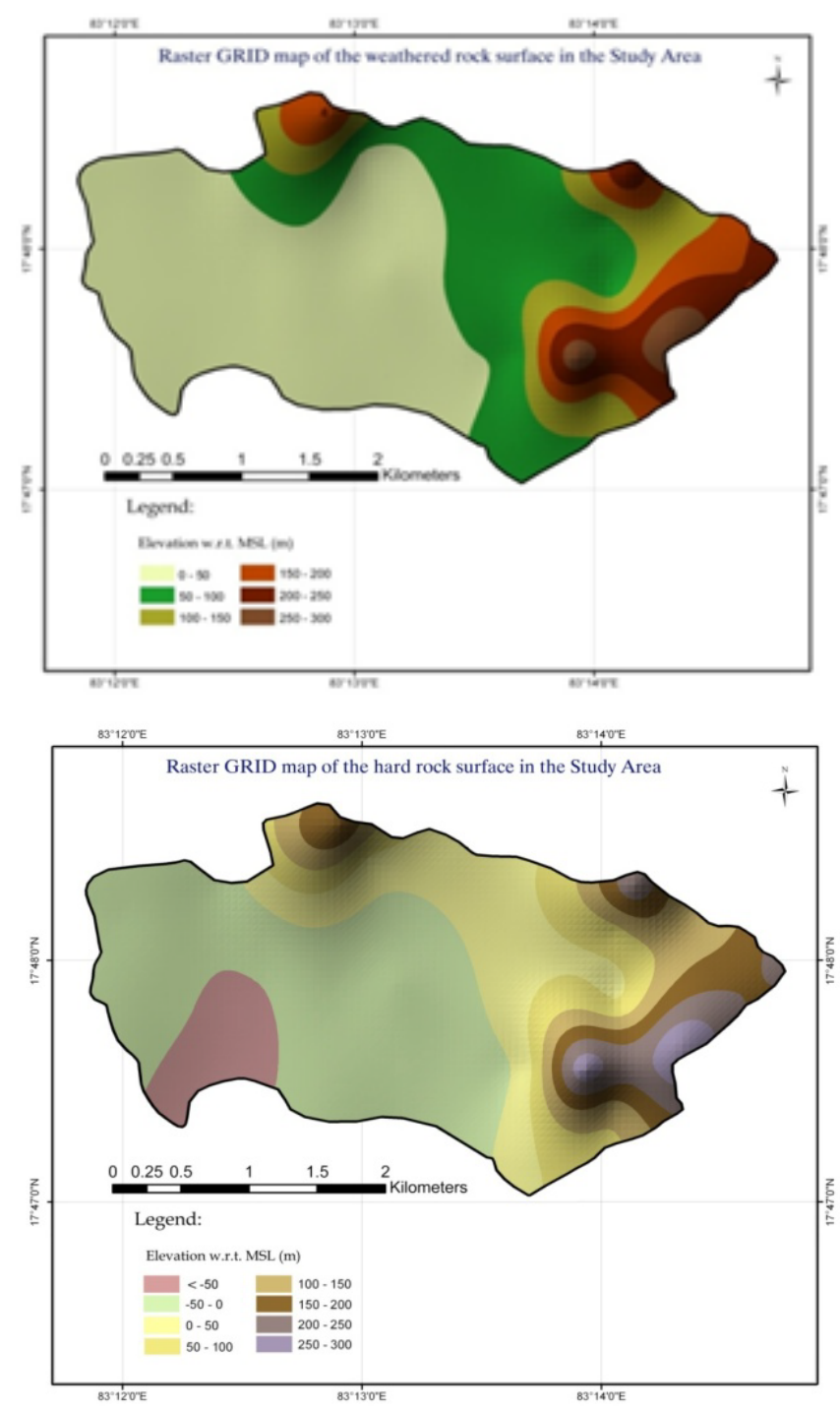

Figure 10: Raster GRID map of weathered rock surface (a) and hard rock surface (b). 
and interpretation of groundwater quality data. GIS has also been considered for multicriteria analysis in resource evaluation [24-28] have carried out groundwater modeling through the use of GIS. In this study the methods to protect the surface water bodies and recharge of groundwater has been suggested with the help of GIS analysis.

\section{Volume estimation of the aquifer system}

The thickness of the subsurface layers at any point in the study area is the difference between the topographic surface elevation and the subsurface under consideration. The elevation value of a given raster cell represented in the subsurface under consideration, if subtracted from the value of the corresponding cell in the topographic surface, yields the thickness of the overburden. The volumetric difference calculated between the GRIDs of topographic surface (Figure $7 \mathrm{~b}$ ) and hard rock surface (Figure 10b), using Raster Math utility in ArcGIS-3D Analyst module, has resulted $416.1 \times 106 \mathrm{~m}^{3}$ of water holding/yielding zone.

\section{Isopach generation}

Isopachs are the lines joining the points of equal thickness of the different units used generally to represent the subsurface layers. The thickness values of the water yielding zone in the area extracted by subtracting the hard rock surface (Figure 10b) from the topographic surface (Figure $7 \mathrm{~b}$ ) were classified in Arc GIS by grouping all the cells into 5 classes [29]. The isopach map thus obtained, Figure 11a, indicates that the thickness of the water yielding zone is within 20 meters range in the hilly and pediment zones whereas the maximum thickness of more than 60 meters is in the central parts of the area which is supposed to be high groundwater potential zone.

\section{Protection of surface water bodies}

Nonpoint source water pollution, also known as polluted runoff, comes from diffuse or scattered sources in the environment rather than from a defined outlet such as a pipe. As water moves across and through the land it picks up and carries away natural and human-made pollutants depositing them into lakes, rivers, wetlands, coastal waters, and even our underground sources of drinking water.

Nonpoint source pollution is the leading remaining cause of water quality problems. The effects of nonpoint source pollutants on specific waters vary and may not always be fully assessed. However, we know that these pollutants have harmful effects on drinking water supplies, recreation, fisheries, and wildlife and we should work together to reduce and prevent nonpoint source pollution. To achieve this, a trench is proposed inside the tank bund (Figure 12) to control the Nonpoint source pollution. The details of which are shown in Figure 13

The material in the tank bed should be removed to increase the storage capacity of the tank (Figure 12a). Dykes are to be constructed inside the trench, which will guide the rainwater through the water inlet (Figure 12b) into the tank. A trench around the sujatha nagar tank is excavated (Figure 12c) during the study to assess the impact of the solution and found to be very useful, as tress passing of the tank bed is restricted.

\section{Aquifer system}

The raster GRID model of the topographic surface is used to simulate the drainage network, which is analyzed with the built-up area (Figures 9a and 9b) resulted the sources of rainwater contamination. The geophysical investigations carried out at various locations in the study area has revealed the subsurface lithological conditions from which the depth to weathered rock, fractured rock and hard rock surfaces, with respect to MSL elevations, has been determined. As the hard rock surface forms an impermeable surface, the thickness of the overburden above it, i.e. combined thickness of soil, weathered rock and fractured rock formations, is estimated to study the aquifer system.

As the hard rock is present directly below the soil cover over the hill slopes, contour trenches are suggested to hold the runoff temporarily, which discharges the runoff into the nearby natural streams in due course of time. These hill slopes and the sides of the natural drains are to be protected by means of vegetative measures like shrubs/grass lands, turfing etc.

It is observed that there is a thickness of more than $60 \mathrm{~m}$ of aquifer zone present in the central part of the study area which can hold a very good amount of groundwater. The soil cover in the study area is less than $5 \mathrm{~m}$ thick and the proposed recharge well of $5 \mathrm{~m}$ depth will be discharging the runoff directly into the weathered rock formation. Considering the maximum porosity of $20 \%$ in weathered rocks, rainfall percolation of $1 \mathrm{~m}$ column gets adjusted into $5 \mathrm{~m}$ thick formation and the zone of saturation i.e. water table raises to $5 \mathrm{~m}$.

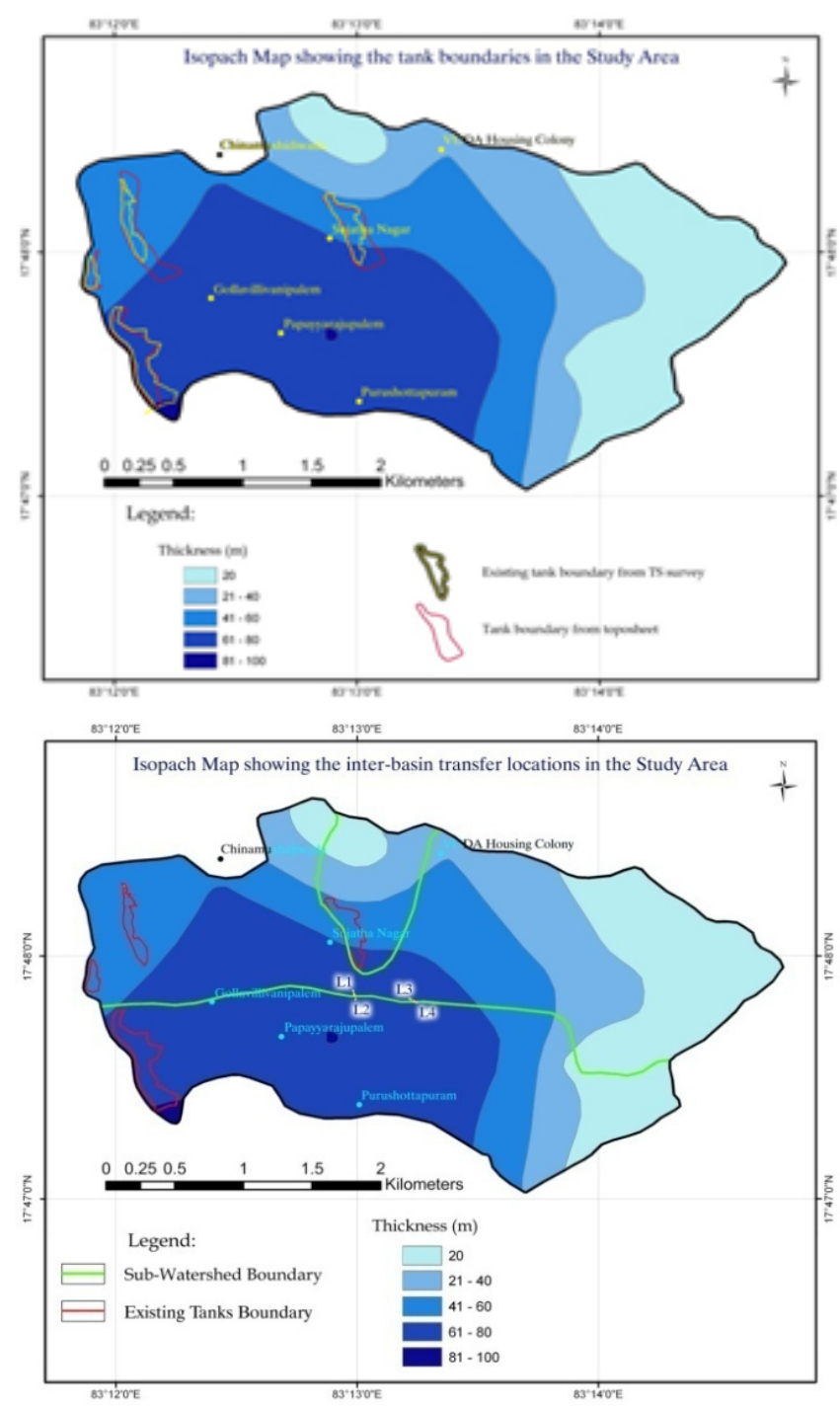

Figure 11: Isopach map showing the tank boundaries (a) and inter-basin transfer locations L1, L2, L3 and L4 (b) in the study area. 


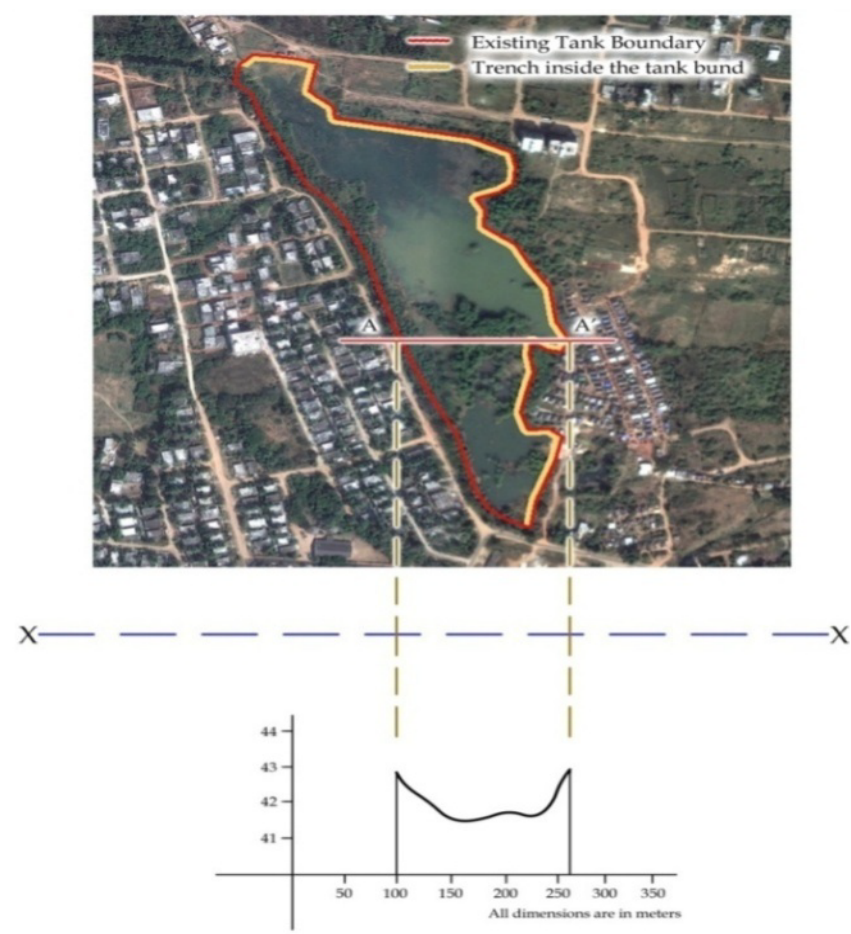

Figure 12: Plan showing the trench inside the existing Sujatha nagar tank boundary and vertical cross-section along the traverse A-A'.

(a)
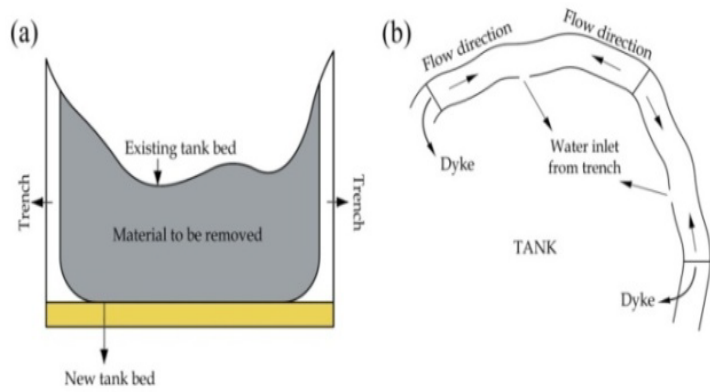

(c)

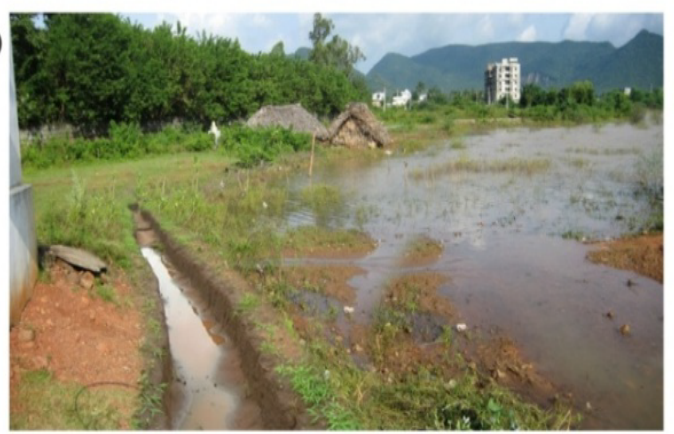

Figure 13: Vertical cross-section of the existing Sujatha nagar tank showing the material to be removed (a), Plan view of the trench around the tank bundshowing the dykes (b) and Photograph showing the trench excavated inside the Sujatha nagar $\operatorname{tank}(\mathrm{c})$.

\section{Surface water bodies}

Improving the water carrying capacity: It is suggested that each water body should be deepened to minimum of $3 \mathrm{~m}$ depth for the entire tank bed and the carrying capacity of each water body is estimated and given in the following Table 2. Thus, the developed water bodies become the decentralized storage systems and transported water from other sources can be stored without creating new reservoirs, to avoid the problems of land acquisition and rehabilitation cost.

Storage capacities of the tanks can be increased, if a minimum of $3 \mathrm{~m}$ depth of water stored throughout the tank bed area.

- The tanks are in the midst of well-developed colonies and the satellite image clearly shows that residential layouts are abutting the foreshore area. There is an immediate need to protect these tanks from occupation.

- Some part of the tank can be developed into a recreational area using the silted material.

- These tanks have its own catchment to get the required quantity of water. Water stored in it will be more useful as groundwater recharge source to the downstream colonies.

Protection measures: Encroachment into the water bodies like streams or tanks is common with intense growth of urban built-up units. Several water bodies in the well-developed area of the city already disappeared and the recent high resolution satellite imagery clearly indicating the new layouts in the foreshore areas of the tanks. We may not be able to vacate the encroached areas once it is occupied with buildings. Hence some physical protection measures are to be taken in the developing areas, before somebody encroached.

The water bodies also need protection from sewerage pollution from the urban area. Even though the water body is protected; it becomes more dangerous if we store the polluted water in it. The following are some of the measures to be taken up to protect the water bodies.

- Tank bed area can be protected by making trenches along the border of the foreshore area as well with permanent markings and continuous monitoring.

- Streams/drains can be protected with fencing, permanent stone markings on either side of the stream with continuous monitoring.

- Underground sewerage system is one of the best techniques, as the sewage from the households will be collected directly and treated in the treatment plants before its disposal, which reduces the contamination of natural drains.

- Water quality control ponds and wetlands, as physical and biological treatment systems, should be adopted.

- Incorporation of gross pollutant traps on inlets of tanks, water quality control ponds and wetlands to intercept trash, debris and the coarser fractions of sediment.

- Proper disposal of pet/animal wastes and litter reduces the oxygen demanding substances, nutrients and bacteria entering into the storm water.

- Reduction in sediment and many associated contaminants can be achieved through proper planning of parking places and regular street cleaning.

\begin{tabular}{|c|c|c|c|c|}
\hline S. No. & Name of the tank & $\begin{array}{c}\text { Tank bed } \\
\text { area } \mathbf{( H a )}\end{array}$ & $\begin{array}{c}\text { Depth } \\
\text { of water } \\
\mathbf{( m )}\end{array}$ & $\begin{array}{c}\text { Estimated capacity } \\
\text { in MCM }\end{array}$ \\
\hline 1 & Sujatha nagar tank & 8.68 & 3 & 0.26 \\
\hline 2 & Chinamushidiwada tank & 9.81 & 3 & 0.29 \\
\hline 3 & Laxmipuram tank & 9.28 & 3 & 0.28 \\
\hline
\end{tabular}

Table 2: Carrying capacity of each identified water body in the study area. 
- Sewerage treatment plant may be required at the confluence points of the stream with the tank due to the presence of welldeveloped colonies in its catchment and presently there is no under ground drainage (UGD) system in this area.

\section{Conclusions}

The present study is limited to the improvement of storage capacity of the tanks and also development of groundwater scenario in the study area. Development of these water bodies may be taken up in a phased manner depending on the need and protection from encroachments.

Comprehensive planning is an effective non-structural tool to control nonpoint source pollution. Where possible, growth should be directed toward areas where it can be sustained with minimal impact on the natural environment. Poorly planned growth and development have the potential to degrade and destroy natural drainage systems and surface waters [30].

In order to use land optimally, it is not only necessary to have the information on existing land use/cover but also the capability to monitor the dynamics of land use resulting out of both changing demands of increasing population and forces of nature acting to shape the landscape. Change detection analysis is carried out as the study area has witnessed remarkable expansion, growth and developmental activities such as building, road construction and many other anthropogenic activities. This has therefore resulted in increased land consumption, modification and alterations of land use/cover over time without any detailed and comprehensive attempt.

Urban water systems must include not only the reservoirs, groundwater wells and aqueducts that are the sources of water supplies needed to meet the varied demands in an urban area, but also the water treatment plants, the water distribution systems that transport that water, together with the pressures required, to where the demands are located. Once used, the now wastewater needs to be collected and transported to where it can be treated and discharged back into the environment.

Well-designed and operated urban water systems are critically important for maintaining public health as well as for controlling the quality of the waters into which urban runoff are discharged. In most urban areas in developed regions, government regulations require designers and operators of urban water systems to meet three sets of standards. Pressures must be adequate for fire protection, water quality must be adequate to protect public health, and urban drainage of waste and storm waters must meet effluent and receiving water body quality standards. This requires monitoring as well as the use of various models for detecting leaks and predicting the impacts of alternative urban water treatment and distribution, collection system designs and operating, maintenance and repair policies.

\section{References}

1. Lasalmil A, Boulal R (2003) Territorial planning scheme for the Agadir metropolitan area (SATAMA project). Summary report. Franco-Moroccan Cooperation and Min. Delegate of the habitat and the urbanism. Agadir, Agadir urban agency.

2. Karr JR (1991) Biological integrity: A long-neglected aspect of water resources management. Ecol Appl 1: 66-84.

3. May CW, Horner RR, Karr JR, Mar BW, Welch EB (1997) Effects of urbanization on small streams in the Puget sound lowland ecoregion. Watershed protection techniques 2: 483-494.

4. Schueler T (1995) Site planning for urban stream protection. Metropolitan Washington council of governments.

5. Shaver E, Maxted J, Curtis G, Carter D (1994) Watershed Protection Using an Integrated Approach. In stormwater NPDES related monitoring needs, proceedings of an engineering foundation conference held in Mount Crested Butte, Colorado.

6. Schueler T (2008) The impervious cover model: Stream classification, urban sub-watershed management and permitting Chesapeake storm water network.

7. Deacon JS, Soule T, Smith S (2005) Effects of urbanization on stream quality at selected sites in the Seacoast region in New Hampshire, 2001-2003. USGS Scientific Investigations Report 2005-5103.

8. Arendt RG (1997) Growing Greener: Putting Conservation into Local Codes [www.envirolink.org/resource.html?itemid=3679\&catid=6] Natural Lands Trust Inc.

9. Caraco D, Claytor R, Hinkle P, Kwon HY, Schueler T, et al. (2008) Encyclopedia of soil science. Dordrecht, Netherland. Springer, pp: XXIV.

10. Chadha DK (2002) State of art of artificial recharge applied on village level schemes in India. Netherlands national committee of the international association of hydrogeologists (NNC-IAH).

11. Tuinhof A, Olsthoorn T, Heederik JP, de Vries J (2002) Management of aquifer recharge and subsurface storage - A promising option to cope with increasing storage needs. Netherlands national committee of the international association of hydrogeologists, NNC-IAH.

12. Davis GH (1982) Prospect risk analysis applied to groundwater reservoir evaluation. Ground Water 20: 657-662.

13. Matheron G (1971) The theory of regionalized variable and its applications. Les cahiers du Centre de Morphologic Mathematique de Fountainbleau 5, Ecole Nationale Superieur de Mines de Paris pp: 211.

14. Chayes F, Suzuki Y (1963) Geological contours and trend surfaces. J Petrology 4: 307-312.

15. Davis JC (1973) Statistics and Data Analysis in Geology. John Wiley and Sons, Inc, New York, pp: 550.

16. Jaiswal RK, Mukherjee S, Krishnamurthy J, Saxena R (2003) Role of remote sensing and GIS techniques for generation of groundwater prospect zones towards rural development: An approach. Int J Remote Sens 24: 993-1008.

17. Krishnamurthy JN, Venkatesa K, Jayaraman V, Manivel M (1996) An approach to demarcate ground water potential zones through remote sensing and geographical information system. Int J Remote Sens 17: 1867-1884.

18. Murthy KSR (2000) Groundwater potential in a semi-arid region of Andhra Pradesh: A geographical information system approach. Int J Remote Sens 21 1867-1884.

19. Obi Reddy GP, Chandra Mouli K, Srivastav SK, Srinivas CV, Maji AK (2000) Evaluation of groundwater potential zones using remote sensing data: A case study of Gaimukh watershed, Bhandara district, Maharashtra. J Indian Soc Remote Sens 28: 19-32.

20. Pratap K, Ravindran KV, Prabakaran B (2000) Groundwater prospect zoning using remote sensing and geographical information system: a case study in Dala-Renukoot Area, Sonbhadra District Uttar Pradesh. J Indian Soc Remote Sens 28: 249-263.

21. Singh AK, Prakash SR (2002) An integrated approach of remote sensing geophysics and GIS to evaluation of groundwater potentiality of Ojhala sub watershed, Mirzapur District, U.P.

22. Rokade VM, Kundal P, Joshi AK (2007) Groundwater potential modeling through remote sensing and GIS: a case study from Rajura Taluka, Chandrapur District, Maharastra. J Geol Soc India 69: 943-948.

23. Srinivasa Rao Y, Jugran KD (2003) Delineation of groundwater potential zones and zones of groundwater quality suitable for domestic purposes using remote sensing and GIS. Hydrogeol Sci J 48: 821-833.

24. Shahid S, Nath SK, Roy J (2000) Ground water potential modeling in soft rock area using GIS. J Remote Sens 21: 1919-1924.

25. Boutt DF, David WH, Bryan CP, David TL (2001) Identifying potential land usederived solute sources to stream base flow using ground water models and GIS. Ground Water 39: 24-34.

26. El-kadi Al, Oloufa AA, Eltahan AA, Malic HU (1994) Use of a geographic information system in site-specific groundwater modeling. Ground Water 32 617-625.

27. Novaline J, Saibaba J, Prasada Raju PVSP (1999) Groundwater modelling for 
Citation: Jalem K (2016) Development of Water Resources for Micro Watershed at Chinamushidiwada Village in Visakhapatnam, Andhra Pradesh, India. J Civil Environ Eng 6: 258. doi: 10.4172/2165-784X.1000258

Page 10 of 10

sustainable development using GIS techniques. Preconference volume 264267 Geoinformetis Beyond 2000, Dehradun, India.

28. Saraf AK, Choudhury PR, Roy B, Sarma B, Vijay S, et al. (2004) GIS based surface hydrological modelling in identification of groundwater recharge zones. Int J Remote Sens 25: 5759-5770.
29. Nageswara RK, Udaya BRC, Venkateswara RT (2008) Estimation of sediment volume through geophysical and GIS analysis: A case study of the red sand deposit along Visakhapatnam coast. J. Ind. Geophys. Union 12: 23-30.

30. Mantel MA, Harper SF, Propst L (1990) Creating successful communities: A guide book to growth management strategies. Island Press, Washington, DC. 